\title{
Diversidade no pensar e nas
}

\section{práticas jornalísticas}

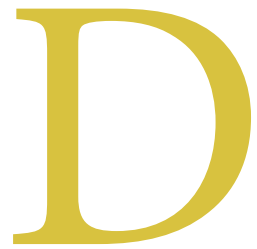

iversidade de abordagens, reflexões e perspectivas que são originárias da relação entre as questões teóricas e as práticas jornalísticas, assim como de outros campos sociais e áreas do saber. Este é o mote do volume 14 de Estudos em Jornalismo e Mídia - EJM, a primeira edição de 2017. Está composta por oito artigos de Temas Livres, uma entrevista e uma resenha, além de já lançar o tema da próxima edição deste ano que será comemorativa aos dez anos do Programa de Pós-graduação em Jornalismo (PosJor) da UFSC.

$\mathrm{O}$ artigo que abre a seção Temas Livres aborda "Memória, esquecimento e a (res)significação da ditadura pela CNV e pela imprensa", de autoria Fernanda Nalon Sanglard e Teresa Cristina da Costa Neves. Tem como perspectiva o campo da comunicação e as discussões sobre memória e esquecimento para análise da Comissão Nacional da Verdade (CNV), as conclusões e recomendações desse documento e também relatos sobre o episódio publicados na Folha de S. Paulo, G1, Jornal Nacional, O Estado de S. Paulo e O Globo.

"Sobre o papel das agências de Relações Públicas durante guerras e conflitos internacionais", de autoria de Regina Cazzamatta, observa o trabalho de agências de Relações Públicas (RP) durante períodos de guerras e conflitos por meio de estratégias como a construção da imagem do inimigo, desinformação, eufemismos, veiculação de notícias encenadas, etc. O texto reúne estudos de casos que mostram o envolvimento de empresas de RP nas Guerras dos Balcãs e Kosovo (1999), do Cáucaso (2008) e do Golfo (1991).

Após estas abordagens sobre questões históricas, o terceiro trabalho, de autoria de Juliana Bulhões e Gustavo Leite Sobral, trata também sobre aspectos históricos, porém com tema mais específico, relacionado à Literatura. É um ensaio com viés biográfico acerca da trajetória de Rachel de Queiroz no jornalismo, enfatizando sua atuação na revista O Cruzeiro, entre os anos de 1944 e 1975.

Após esses olhares situados no jornalismo brasileiro, o quarto artigo discorre sobre um valor capital do jornalismo: a credibilidade. As autoras Silvia Lisboa e Marcia Benetti propõem uma abordagem do conceito de credibilidade a partir da articulação do jornalismo com a corrente filosófica da Teoria do Conhecimento e com as teorias discursivas, através da distinção de duas dimensões: a credibilidade constituída do enunciador e a credibilidade percebida pelo interlocutor.

$\mathrm{Na}$ sequência, o quinto tema possui relações estreitas com a questão da credibilidade, em que os autores José Tarcísio Silva Oliveira Filho e Iluska Coutinho dissertam a respeito da qualidade no telejornalismo público. O paper propõe uma matriz para avaliar a qualidade da TV Pública, tendo o noticiário Repórter Brasil Segunda Edição (TV 
Brasil) como objeto empírico.

Seguindo a perspectiva de compreensão do jornalismo em seu caráter público, o sexto artigo destaca a relação entre jornalistas e fontes, tendo como objeto empírico a cobertura do impeachment da presidenta Dilma Rousseff no radiojornal CBN Rio. O autor Luan José Vaz Chagas investiga a seleção das fontes e os argumentos com base em questões que possibilitaram impedimentos na América Latina durante as últimas décadas.

O sétimo artigo, de Alciane Baccin, reflete e retoma a evolução da narrativa no ambiente digital, com o objetivo de compreender o papel da narrativa longform na reportagem hipermídia, destacando suas características. Além dessa temática voltada aos avanços tecnológicos na prática de narrar, outra questão contemporânea é abordada no oitavo artigo, que se refere a uma questão muitas vezes invisibilizada: as pessoas com deficiência. Os autores Carlos Alberto Zanotti e Bárbara Garcia Pedroso investigam de que forma profissionais da imprensa que possuem algum tipo de deficiência física, intelectual ou visual constroem sentidos a respeito da autonomia e das discriminações enfrentadas por esse grupo social, em especial no que diz respeito ao mercado de trabalho.

$\mathrm{Na}$ seção Entrevista, Antônio Carlos Hohlfeldt, que presidiu a Intercom entre 2008 e 2014, avalia as conquistas do congresso para a área da comunicação, discute os desafios que a pesquisa em Jornalismo tem pela frente, mediante os questionamentos dos entrevistadores Cândida Oliveira e Dairan Paul. A edição é encerrada com a resenha "O bom jornalismo não morre, se reinventa”, de autoria de Géssica Gabrieli Valentini, sobre o livro "Jornalismo Inovador na América Latina” (2017), organizado pelos editores norte-americanos Teresa Mioli e Ismael Nafría.

$$
* * *
$$

Além de apresentarmos essa edição, aproveitamos para lançar o tema da próxima edição de 2017 que será comemorativa aos dez anos do Programa de Pós-graduação em Jornalismo
(PosJor) da UFSC. Antes disso, cabe recordarmos um pouco desta trajetória...

Quando um grupo de professores da UFSC empreenderam esforços para a elaboração de um projeto para uma pós-graduação em Jornalismo, no início dos anos 2000, enfrentaram muitos questionamentos. Por que se fechar no Jornalismo, se a Comunicação é um campo tão amplo? Por que restringir os esforços no Jornalismo se este nem é uma ciência? Para rebater a tantos julgamentos apressados, esta equipe precisou de paciência e perseverança, estudos, debates, desenvolvimento de pesquisas, produção científica qualificada para responder à comunidade acadêmica mais com ações do que com palavras.

Em finais de 2006 o Ministério da Educação autorizou a instalação do Programa de Pós- graduação em Jornalismo da UFSC. As justificativas foram finalmente acatadas. A proposta do Posjor nunca foi se fechar simplesmente no Jornalismo por capricho ou por corporativismo, muito menos por um grupo se sentir privilegiado ou superior a outro. Mas por perceber a necessidade de conhecer com mais profundidade as especificidades do campo. O Jornalismo realmente não é reconhecido como uma ciência, mas é uma prática sociocultural que requer uma teoria específica, como demonstrou Adelmo Genro Filho. Este abarca tantas questões que carecem de compreensão. Finalmente, os estudos em nossa área concentram-se no tema, mas não se fecham em termos teóricos e metodológicos. Ao contrário, são abordagens interdisciplinares que estendem os olhares a muitos outros campos como a história, a filosofia, a sociologia, a antropologia, entre outros.

Nesses dez anos, o Programa formou uma centena de mestres. São dissertações que tratam de temas variados nas duas linhas de pesquisa: 1 . Jornalismo, Cultura e Sociedade e 2. Tecnologias, Linguagens e Inovação no Jornalismo. Em 2014, a Capes autorizou o funcionamento do Doutorado e a primeira tese será defendida já em outubro deste ano. Esta será a primeira 
defesa de doutorado em Jornalismo em toda a América Latina no Século XXI. No mesmo ano de 2014, o Posjor passou a acolher pesquisadores em estágio pós-doutoral. Tantas outras atividades como seminários, palestras, colóquios promovidos pelo Programa ajudaram a elevar e fortalecer a massa crítica de nosso campo.

Por isso mesmo, Viva! O Posjor faz dez anos! São dez anos de estudos, esforços e vigilância de propósitos.

E a revista Estudos em Jornalismo e Mídia acompanha essa trajetória. Fundada em 2004, a EJM teve contribuição importante na disseminação de ideias e produções do nosso campo. De certa forma, ajudou a pavimentar o terreno em que se construiu o projeto do Posjor. Assim, as equipes do Posjor e da EJM sentem-se privilegiadas por viverem este momento e neste clima de comemoração dos dez anos do PosJor lançamos o tema da próxima edição da EJM que irá tratar da "Pós-Graduação em Jornalismo no Brasil". Em breve, lançaremos a chamada de artigos para submissão.

Boa leitura!

Jorge Kanehide Ijuim

Daiane Bertasso Ribeiro 